\title{
ALIGNING TECHNOLOGICAL AND INSTITUTIONAL CHANGE: MARITIME TRANSPORT IN WEST MEDITERRANEAN SEA
}

\author{
Alberto Asquer ${ }^{\star}$
}

\begin{abstract}
Within the area of study of infrastructure, various works have addressed the issue of the development of technological and institutional systems of network industries. In a dynamic perspective, issues arise about how technology and institutions co-evolve, what stimulates improvement of infrastructure performance, and how formal institutions should be designed in order to facilitate technological and institutional co-evolution. Building on the coherence framework for performance in network industries, this study aims to contribute to the development of an improved theory of technological and institutional change in network industries. The theoretical developments are illustrated through the case of technological and institutional changes of the maritime transport industry in West Mediterranean Sea. The results suggest that more attention should be placed on the variety of private and public dimensions of performance of the network industry and by the mutual interaction between status quo conditions in the technological and institutional systems.
\end{abstract}

Keywords: maritime transport industry; port reform; technological and institutional coherence

\footnotetext{
Lecturer of Business Strategy and Policy, Dipartimento di Scienze Economiche ed Aziendali, Faculty of Economics, University of Cagliari, Italy, Viale Fra Ignazio 17 - 09123 Cagliari, Phone: +390706753399, Email: aasquer@unica.it.

The author would like to thank Prof. Matthias Finger, Prof. Rolf Künneke, and two anonymous referees for their comments and suggestions to previous versions of this paper.
} 


\section{INTRODUCTION}

Within the field of study of infrastructure regulation, various works have addressed the issue of the coherence between technology and institutions of infrastructure industries (Finger et al., 2010; Duthaler and Finger, 2010; Crettenand et al., 2010; Finger and Künneke, 2009, 2006; Scholten, 2005; Finger and et al., 2005). These studies - especially those related to the design and development of the so-called "coherence framework for performance in network industries" - posit that the degree of technological and institutional coherence affects, in conjunction with context conditions such as sector-specific features and time-dependent constraints, both technical, economic, and social performance of infrastructure. Within this body of literature, coherence between technology and institutions of infrastructure industries is related to comparable coordination mechanisms, scope of control, coherence in resolution, and coherence between speed of adjustment. The achievement of coherence, in turn, is affected by requisite functions that need to be performed in order for the infrastructure to run properly, such as interoperability, interconnection, system management, and capacity management (Finger et al., 2005).

Parts of these studies have recently focused on how technological and institutional coherence is achieved over time (Finger et al., 2010; Crettenand, 2011). From a dynamic perspective, issues arise about how technology and institutions co-evolve, whether co-evolution results in improvement of infrastructure performance, and how formal institutions should be designed in order to facilitate the convergence between technological and institutional systems. Arguably, changes of the installed technological systems depend on R\&D and investment decisions made by actors that own, control, and operate the infrastructure network. Additionally, changes of the institutional arrangement of infrastructure industries depend on efforts that actors within the infrastructure policy domain exert in advocating for, designing, and coming to agree on the reformulation of rules for governing the infrastructure. Attention to actors' role (i.e., to agency), therefore, seems important in order to finetune our understanding of the process of technological and institutional co-evolution.

The aim of this study is to contribute to the development of an improved theory of technological and institutional change by addressing the issue of how technological and institutional systems converge, or fail to converge, towards increased coherence. By addressing this issue, this study makes use of the coherence framework as the basis for the development of broaden theories of technological and institutional change in network industries. In so doing, this study is aligned to a few others (Finger et al., 2010; Crettenand, 2011) that have started extending the original functions of the coherence framework, namely to explain performance in network industries and to advising how technological and institutional systems should change, towards one to account for the process through which technological and institutional systems co-evolve. Additionally, a better understanding of how technological and institutional systems converge, or fail to converge, towards increased coherence is important in 
Alberto Asquer

order to provide well-founded explanations for network industry performance and sound policy advice.

This study tackles, in particular, the question of why technological and institutional systems do not converge towards increased coherence in spite of evidence of dissatisfying performance in the network industry. From an evolutionary economy perspective (Nelson and Winter, 1982; Dosi, 1982; Dosi and Nelson, 1994), technological and institutional systems that result in dissatisfying performance should be supplanted by the emergence of alternative and better performing technological and institutional systems devised by innovative agents. How is it possible that technological and institutional systems are persistently "stuck" with configurations that fail to meet actors' performance expectations? This question calls for developing a theoretical argument that accounts for why actors may fail to develop a desire for improving the performance in the network industry, or may lack the willingness to direct efforts and resources to changing technological and institutional systems, or may not be able to channel their efforts and resources towards improved coherence between the technological and institutional systems of the network industry. Answers to this question, in other words, should account for what hampers the unfolding of "evolutionary mechanisms" that would otherwise result in the progressive alignment between technological and institutional systems as actors strive for improved performance.

This study consists of an exploratory case study of the technological and institutional systems of the maritime transport industry in West Mediterranean Sea. Maritime transport is an important infrastructure-based network industry that channels most of nowadays' global trade (about $90 \%$ in volume, $70 \%$ in value terms). The maritime network is formed by ports (elements of maritime-land interface), regular routes (port-to-port, pendulum, and round-the-world), and various kinds of vessels for the transport of passengers (liners and cruisers) and freight (bulk carriers, general cargo, container ships, and roll on-roll off vessels). Traditionally, most of harbor activities used to be performed by the same operator (generally a public port authority), possibly in conjunction with a restricted number of private concessionaires that generally were not subjected to any tight competitive pressure. Since some decades, however, several governments adopted port reforms that aimed to modernize, liberalize, and privatize harbor activities, whose benefits have been highlighted by several advisory organizations (e.g., the Public-Private Infrastructure Advisory Facility and the World Bank) and scholarly works (Estache et al., 2001, 2003; Tongzon and Heng, 2005; Defilippi, 2010).

Historically, technological change played an important role in the industrial restructuring and performance improvement of maritime transport networks. During the last century, the maritime industry was significantly affected (at both the global and local scale) by intense modification of water canals (including dredging port channels to higher depths), increase of size and specialization of vessels, enhanced automation and speed of operations, and better ship design and energy efficiency. The 
diffusion of containers since the 1970's, in particular, dramatically improved the performance of transporting and handling bulky items. Traffic of container ships is still the fastest growing segment of the maritime transport industry nowadays. Additionally, the introduction of innovative services in ports also helped to speed up loading and off-loading activities and to increase flexibility in shipowners' choice of which port to service. Also changes in the institutional regimes of maritime transport bore significant effects on the organization and performance of maritime transport networks. When harbors are controlled by public port authorities in conjunction with a restricted number of private concessionaires, maritime transport activities may be hindered by rather complex and opaque regulatory systems, that tend to discourage (or effectively block) potential new entrants, obfuscate pricing decisions, and overshadow collusive practices between operators (e.g., the so-called "conferences" or consortia between shipping companies). In contrast, port infrastructure performance seems to increase when harbors are managed by independent and decentralized operators (Estache et al., 2001), although vertical separation of port segments may result in diseconomies of scope or coordination (Defilippi, 2010).

The rest of the paper is organized as follows. Next section will discuss some steps for the development of an improved theory of technological and institutional change in network industries on the basis of the coherence framework. Section three will outline the general traits of the maritime transport industry. Section four will present the case of maritime transport industry in West Mediterranean Sea - especially, by focusing on industrial issues and policy change at the level of the EU and of selected EU member states (France, Italy, and Spain). Section four will discuss how the proposed theoretical developments can contribute explaining the observed dynamics of the case of the maritime transport industry. Finally, section five will draw the conclusions.

\section{TOWARDS A THEORY OF TECHNOLOGICAL AND INSTITUTIONAL CHANGE IN NETWORK INDUSTRIES.}

The general scholarly literature on infrastructure economics and regulation addresses the various technical, economic, and political issues that arise in the management of infrastructure systems. Within this body of knowledge, more focused attention has been placed, recently, on issues related to the conditions that facilitate the technical functioning of infrastructure (Finger et al., 2005; Finger and Künneke, 2006, 2009). These studies highlighted that the functioning of infrastructures is primarily dependent upon the coordination of activities within physical networks that extend over relatively large geographical areas, involve different technologies and standards, and are subjected to influence from various actors that typically pursue partially conflicting objectives (Economides, 1996; Göttinger, 2003). Managing infrastructure requires, therefore, performing coordination of activities and synchronization of 
Alberto Asquer

tasks in order to guarantee that essential conditions for delivering infrastructurebased services are met.

The allocation of the functions of coordinating activities and synchronizing tasks within infrastructure depends on the institutional arrangement of the infrastructure (i.e., sectoral-specific institutions, as contrasted to general institutions of the domestic or super-national environment; Glachant and Finon, 1999). Traditionally, these functions have been often performed by centralized systems of planning and control, typically administered by public authorities (Geels, 2004; Gibbons and Gwin, 1985). Within the contemporary political and policy context, however, infrastructures often lack any centralized planning and control authority. Rather, various actors exercise control over selected portions of infrastructure networks, subjected to a regulatory regime that provides the terms and conditions for sharing access to the infrastructure, setting prices, and allocating costs for the development and use of the infrastructure network (Kessides, 2004; Newberry, 2001). Such 'decentralized' industrial organization, however, may result in worsened performance, provided that network externalities, various kinds of asset specificity, and the abuse of dominant positions or collusive practices between relatively few network operators account for the possibility of failure of market-based mechanisms of coordination (Williamson 1975, 1985; Coase, 2005; Ménard, 2005).

The framework of technological and institutional coherence is especially focused on explaining what affects performance in network industries. The coherence framework is attentive to disentangle performance into various dimensions (Finger et al., 2005; Crettenand et al., 2010; Duthaler and Finger, 2010), namely economic performance (in terms of both static, dynamic and system efficiency), public value creation (in such terms as quality, accessibility, affordability and reliability of the service, and environmental preservation and protection), and assurance of technical system integrity. Ensuring the technical integrity of infrastructure systems relates to the management of four distinct network functions, namely interconnection (i.e., managing the physical linkages between different networks that perform similar or complementary tasks), interoperability (i.e., facilitating the complementarities between components of different networks), system management (i.e., coordinating and controlling the material and information flow across the network), and capacity management (Finger et al., 2005).

The central tenet of the technological and institutional coherence framework is that the degree of coherence between the technical requirements for infrastructure system coordination and the institutional arrangement of the infrastructure system plays a fundamental role in affecting performance in the network industry. This argument is further articulated in both a static and dynamic perspective. In a static perspective, the degree of coherence depends on whether the technological and institutional systems share the same coordination mechanisms (i.e., centralized, decentralized, or peer-to-peer) over comparable network boundaries. High coherence is achieved if the institutional arrangement of the infrastructure system provides the 
rules for facilitating coordination and resolving conflicts between network actors that control or operate in selected parts of the network. The coherence between the technological and institutional systems is expected to result in improved network performance in both the economic, public, and technical dimensions. Low coherence, instead (such as when institutional arrangements do not provide rules for coordination and conflict resolution between autonomous actors), is expected to lead to inferior performance.

In a dynamic perspective, the degree of coherence between the technical requirements for infrastructure system coordination and the institutional arrangement of the infrastructure system is not taken as given, but changes over time. Drawing from an intellectual tradition rooted in evolutionary economics (Nelson and Winter, 1982; Dosi, 1982; Dosi and Nelson, 1994; Schumpeter, 1942), the framework suggests that actors' perception of inferior performance should feed back into informing actors' actions intended to improve the alignment between technological and institutional systems (Finger et al., 2010; Crettenand et al., 2010). Actors' actions should aim to improve coherence between the technological and the institutional systems in terms of coordination mechanisms, scope of control, territorial resolution, and speed of adjustment. If higher coherence is achieved, then infrastructure performance improves because network actors can better overcome structural limitations (constraints) that are inherent, to a different degree depending on the sector and epoch, in any physical infrastructure network (Duthaler and Finger, 2010).

The coherence framework can be extended in various directions (Finger et al., 2010; Crettenand et al., 2010; Duthaler and Finger, 2010). This study is especially concerned with the view that, in the present state, the coherence framework has not fully developed into an improved theory of technological and institutional change in network industries. Additional work on the formulation of a distinctive theory of co-evolution of technological and institutional systems in network industries is needed, however, in order to better perform the original functions of the coherence framework, namely to explain performance in network industries and to advising how technological and institutional systems should change. A broadened theory of technological and institutional change in network industries, in fact, would help explaining performance in network industries in a dynamic, rather than static, perspective, i.e., by accounting for the inability of actors to remedy to a continuously dissatisfying performance over time, rather than for the inadequacy of a given configuration of technological and institutional systems as observed at a certain time. Additionally, a broadened theory of technological and institutional change in network industries would assist the formulation of policy advice, i.e., by providing expectations on how actors in the network industry would react to interventions intended to elicit their efforts to improve coherence between technological and institutional systems.

Within the discipline of economics, evolutionary economics is a theoretical approach that is especially concerned with explaining processes of change in economic systems. From an evolutionary economics perspective, technological and institutional 
Alberto Asquer

changes are broadly explained by a process of "natural selection" akin to the one that characterizes the evolution of biological organisms. According to this view, industries develop through the constant efforts of agents who search, adopt, and test new "ways of doing things" or routines (Nelson and Winter, 1982) that are retained or discarded depending on the level of organizational performance achieved. Broadly conceived, routines encompass both the kind of technology that is used to convert production inputs into outputs as well as the consolidated practices that agents follow within the given institutional arrangement. Technology and institutional change, therefore, results from the evolution of routines that takes place through mechanisms of selection of those routines that allow agents to outperform competitors.

While evolutionary economics accounts for processes of change in economic systems in general, we may wonder to what extent this theoretical approach provides a satisfactory explanatory perspective to the evolution of technology and institutions in network industries, in particular. Within evolutionary economics, the process of "natural selection" is typically conceived as resulting from a market-based selection mechanism where routines that perform better are retained while those that perform worse are discarded, provided that they fail to attract the resources that agents need for survival. This account of change in economic systems seems especially suited to industries characterized by the presence of several agents, free entry and exit of competitors, some scope for product differentiation, independent decision making between agents, and modest market power (i.e., to industries generally related to monopolistic competition in neoclassical analysis). Network industries, however, exhibit quite different features: industry structure is often made by a few agents, industry access is frequently restricted (and, in addition, exit is discouraged by high sunk costs), network services may be relatively undifferentiated (at least, basic ones), agents typically take each others' conduct into account when making decisions, and in many instances one or a few agents enjoy considerable market power with respect to others. It is questionable, therefore, whether the same selection mechanism that drives the evolution of routines can account for the process of technological and institutional change that takes place within network industries.

Some previous studies done on the dynamics of technological and institutional change in network industries suggest that the evolution that takes place in this kind of industries may be driven by other mechanisms but market-based selection. Nightingale et al. (2003), for example, highlighted the role played by improved control systems that are designed and implemented with the aim of attaining a desired performance. Finger and Künneke (2007) showed the role played by gaps between actual and desired performance in rising the aspiration to adapt the technological and institutional systems in order to attain the desired results. Jonker (2010) also discussed how underperformance is supposedly an impulse for adaptation of the technological and institutional systems. In network industries, indeed, technological and institutional change seems driven by deliberate design of novel technological and institutional 
features intended to make agents attain desired performance as much as - if not more than - experimentation of new routines subjected to market testing.

While retaining some conceptual foundations in evolutionary economics, a theory of technological and institutional change in network industries should also build on an explicit consideration for agents' purposeful design choices, strategic interaction, and power relationships. An early step in this direction was made by Finger et al. (2010), who highlighted that institutional and market actors may be interested to attain higher performance expectations, while institutional and technological actors may enjoy the power to change the rules and affect the behavior of market actors. Technological and institutional change, in this view, results from the decisions that actors make while strategically taking into account the objectives and choices made by other actors, and subjected to the constraints provided by the allocation of decisionmaking rights as specified in the institutional environment.

Building on Finger et al.'s (2010) contribution, additional features of a theory of technological and institutional change in network industries should include attention to why actors become interested to attain higher performance expectations and why they exert their power to change rules and technical features of infrastructure. With respect to the attainment of higher performance expectations, the distinction between private and public dimensions of performance seems relevant. Actors can be assumed to care about achieving higher level of performance that relates to their private sphere, such as, for example, firm's profits and politician's votes, and to any of the many dimensions (Karlsson et al., 2007) of the public sphere, such as, for example, efficiency of infrastructure services, equality of access, and environmental preservation. Issues arise, then, with respect to whether it is the aspiration to achieve higher performance in the private or in the public sphere that drives actors' efforts to improve the coherence between technological and institutional systems. In principle, the objectives to attain higher performance in the private and public dimensions are not necessarily conflicting: it is possible that an actor attains higher personal gains if the overall network performance (in any dimension) is improved as well. We cannot rule out, however, that the objective to attain higher performance in the private sphere contrasts with the one of improving any of the public dimensions of performance: it is possible, in fact, that an actor can privately gain while suppressing the overall network performance (e.g,, if the actor has exclusive access to the most lucrative segment of the users basin and the network infrastructure is not developed enough to make room for other operators).

Additionally, we should note that actors can be assumed to decide on the basis of both privately and publicly held information about both actual and expected (desired) performance. In the public sphere, actors generally negotiate a shared understanding, measurement, and assessment of network industry performance. As highlighted by Karlsson et al. (2007), performance of network industries (or, as they put it, of infrastructure) is a multi-faceted construct that is subjected to disputes concerning definition, measurement, and assessment criteria. It is possible, therefore, that actors 
Alberto Asquer

genuinely disagree on what network performance dimensions count, how to measure them, and whether results should be judged as satisfying or not. If any actors hold private information about any actual or desired performance dimension, however, then they may opportunistically manipulate the formation of a shared agreement on network performance (e.g., by claiming that any specific public dimension of performance does not need to be improved, provided that the present state of network performance relates to a satisfying level of performance in the private sphere).

With respect to exerting power to change rules and technical features of infrastructure, coordination between actors' strategies seem especially important. Depending on the institutional environment, the decision to change rules of the network industry may require the concerted efforts of several actors (e.g., forming a winning coalition that meets the requirements of majority rules). The individual decision to change the rules of the network industry, however, may depend on whether any actor expects to reap any performance gains once actors' future behavior is affected by the incentive structure provided by the new rules. Obviously, an actor may resist changes of rules that threaten to undermine established patterns of rent appropriation or any other performance gain that the actor enjoys, given the existing technological and institutional system arrangements. Depending on the technology used in the network industry, moreover, the decision to change the technical features of infrastructure may require the coordination between investment decisions between actors (e.g., coming to agree to adopt commensurate technical devices). Again, the individual decision to invest in any technology may depend on whether any actor expects to gain from future industry behavior. In particular, an actor may refuse or indefinitely postpone investments that subvert the actor's rent or other advantageous position provided by the existing technological and institutional systems.

We can notice, then, that any technological and institutional change in the network industry can be conceived as two intertwined processes. Change of the institutional system may take place, depending on the conditions of existing technological and institutional systems and expected performance effects once the change of rules affects actors' future behavior. Change of the technological system may take place, similarly, depending on the conditions of existing technological and institutional systems and expected performance effects once the investment in new technical features of the system affects future industry behavior. Co-evolution between technological and institutional systems may take place if both these processes are set in motion. It is possible, however, that actors are "stuck" with technological and institutional system that result in overall sub-satisfying performance because of lack of incentives to cooperate in changing the rules and investing in new technical features of the infrastructure.

It seems apparent, then, that marshaling the concerted efforts to improve the technological and institutional coherence in network industries is not an easy task. Actors may be reluctant to invest in new technical features of the infrastructure if the institutional arrangement of the network industry does not provide guarantee that 
actors retain control of their assets and related income streams. Additionally, actors may be unwilling to change the institutional arrangement of the network industry if this undermines the strategic value of actors' assets and threatens future income streams. The legacy of past network industry evolution (resulting in the installed technological systems and institutional arrangement), therefore, places heavy constraints on the possibility that actors may stipulate agreements for investing in new technical features of the infrastructure and reformulating the institutional arrangement of the network industry for the sake of mutually beneficial outcomes.

The rest of this paper contains a case study of the technological and institutional systems of the maritime transport industry in West Mediterranean Sea in 1990's-2000's. The case has been selected because it allows to explore the difficulty encountered in improving technological and institutional coherence of a network industry, within a context characterized by a shared understanding of sub-satisfying overall network performance in the public discourse, by the presence of multiple actors that pursue partially conflicting objectives, and by resistance encountered in realigning the technological and institutional systems of the infrastructure. As such, the case is used to illustrate how actors may remain "stuck" with existing technological and institutional systems despite the fact that they are publicly regarded as conducive to dissatisfying overall performance of the network infrastructure. Drawing from documentary sources, the case study shows how short-sighted and self-interested actors may effectively hamper the realignment of technological and institutional systems within a large transport infrastructure.

\section{THE MARITIME TRANSPORT INDUSTRY: AN OVERVIEW}

The maritime transport industry consists of the economic activity performed through a large and complex infrastructure network primarily based on ports, vessels, and logistic systems (Cullinane, 2011; Robinson, 2002). Within this infrastructure, ports play a fundamental role as key nodes of 'hub-and-spoke' network configurations. Ports host a variety of economic activities, including pilotage, towage, supply of utilities such as water and power, cargo handling, catering, ship repair, and so on (Trujillo and Nombela, 2000; De Rus et al., 1994). Several actors take part to maritime transport activities, including the Port Authorities, port service providers, port users (e.g., carriers, shippers, and tenants), and the maritime workforce. Over time, activities are typically reconfigured depending on the growth of maritime transport demand, the adoption of technological innovations, and changes of the institutional arrangements of the infrastructure system.

The growth of maritime transport demand at the world scale is a main driver of activity reconfiguration in the industry. The intensification of world maritime traffic - in both terms of number and frequency of routes, volume of shipped goods, and 
Alberto Asquer

value of trade - enhanced the competition between ports for attracting larger market shares and more profitable customer segments. The quest for better customer service induced port development planners to strengthen intermodality between ports and other transport networks beyond the port yard - especially, the integration with other components of logistic systems such as railways and highways - and to improve efficiency of terminals. Massive investments, however, are still needed to 'upgrade' installed port infrastructure to match rising standards within the industry - up to an amount that often surpasses the financial burden that port owners (typically, national or local public authorities) can afford.

Technological innovations are a second main force that reshapes the contours of the maritime transport industry. Since the 1970's, containerization (that currently affects more than $60 \%$ of world general cargo trade and $80 \%$ of trade between industrialized countries) dramatically changed the requirements for cargo handling and port facilities. A stream of other innovations - including, for instance, the 'unitization' of goods (i.e., the possibility to re-package cargo items of relatively small size into larger units on the basis of standard formats) and information technology for managing logistics - called for further changes of technical systems adopted in ports. Generally, new technologies require ports to invest in capital-intensive assets (e.g., cranes, vehicles, IT systems) that induce radical shifts within the political economy of the maritime transport industry. In particular, the maritime workforce, once an influential stakeholder of the maritime industry, has lost part of its traditional prerogatives and protections (or is under the threat of losing them) and is exposed to more competitive pressures.

Changes of the institutional arrangement of the infrastructure system, finally, are another main driver of transformation of the maritime transport industry. Generally, ports are governed by a Port Authority (sometimes also called 'port management' or 'port administration'), that is defined as "a State, Municipal, public or private body, which is largely responsible for the tasks of construction, administration and sometimes the operation of port facilities and, in certain circumstances, for security" (EU, 1977). Port Authorities typically exercise public and regulatory powers, such as applying international conventions, laws, and rules, exerting police powers, and, to some extend, making rules that impact on the economic and social conduct of port operators (e.g., safety requirements). Traditionally, Port Authorities often owned and controlled the whole port infrastructure, planned port development, and directly operated most of port services (with greater or lesser degree of government intervention rather than autonomy granted to the Port Authority). Nowadays, Port Authorities may retain ownership of most port infrastructure while sharing most of operations with private operators (i.e., the so-called 'landlord model'). Private participation to port activities may take various forms, such as contracts to build, operate, and transfer (BOT) part of infrastructure, concessions, and renting of port facilities. Provided that in limited circumstances only are private operators subjected to competitive pressures, the Port Authorities generally regulate prices charged for port services by following 
cost-plus rules or targeting the rate of return of private operators' investments in port infrastructure.

\section{THE MARITIME TRANSPORT INDUSTRY IN WEST MEDITERRANEAN SEA}

In the past, the growth of maritime transport demand at the world scale had large repercussions in any industrialized country, including those bordering West Mediterranean Sea. Historically, France, Italy, and Spain hosted some among the main ports through which large part of Europe's maritime trade with the rest of the world transited (e.g., Marseille, Genoa, Barcelona, Valencia). By and large, however, nowadays Mediterranean French, Italian, and Spanish ports struggle to compete for maritime traffic to/from Europe, especially with respect to Northern European harbors (e.g., Rotterdam, Antwerp, Hamburg). Pictures 1 and 2 show the total volume of inward vessels traffic and of shipped goods (both inwards and outwards) in Mediterranean French, Italian, and Southern Spanish ports with respect to Northern French, German, Belgian, Dutch, and Danish ones.

Picture 1. Total volume of inward vessels tonnage (gross tonnage in million) in Northern (Northern French, German, Belgian, Dutch, and Danish) harbors and in West Mediterranean (Mediterranean French, Italian, and Southern Spanish) harbors, net of passenger liners and cruise ships, quarterly data, 1997-2010 (source: Eurostat, 2011)

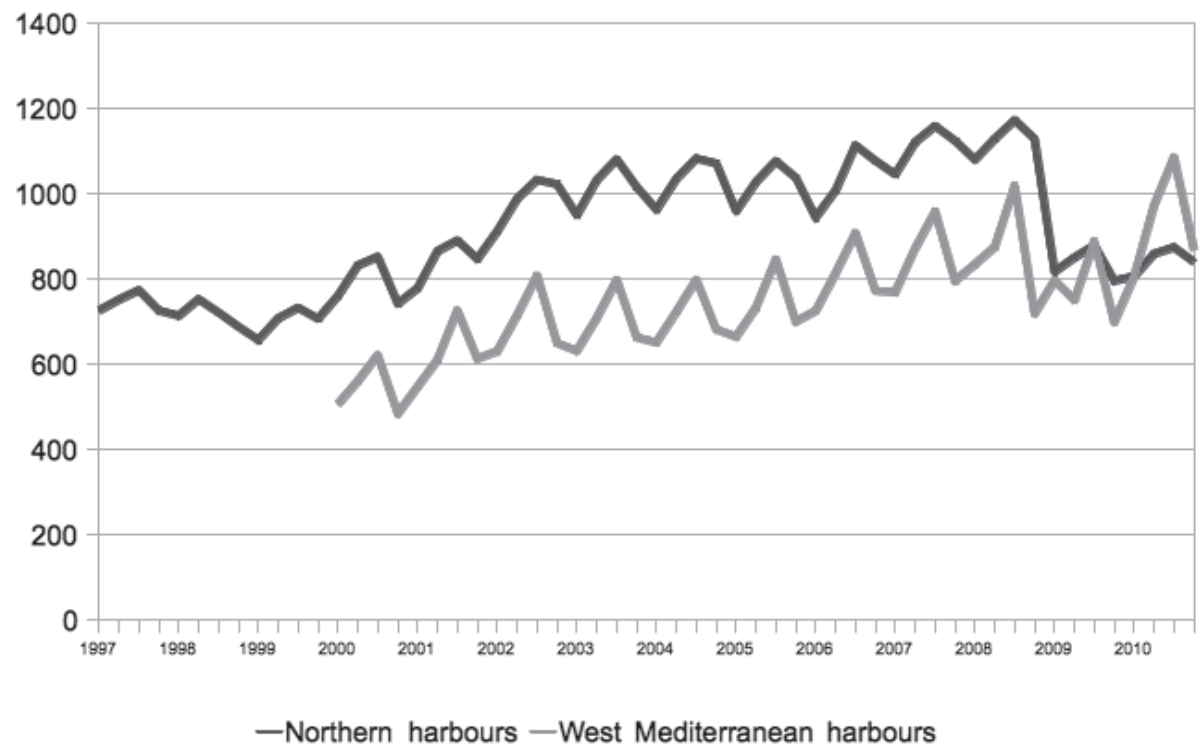


Alberto Asquer

Picture 2. Total volume of shipped goods (both inwards and outwards) (million tons) in Northern (Northern French, German, Belgian, Dutch, and Danish) harbors and in West Mediterranean (Mediterranean French, Italian, and Southern Spanish) harbors, quarterly data, 1997-2010 (source: Eurostat, 2011)

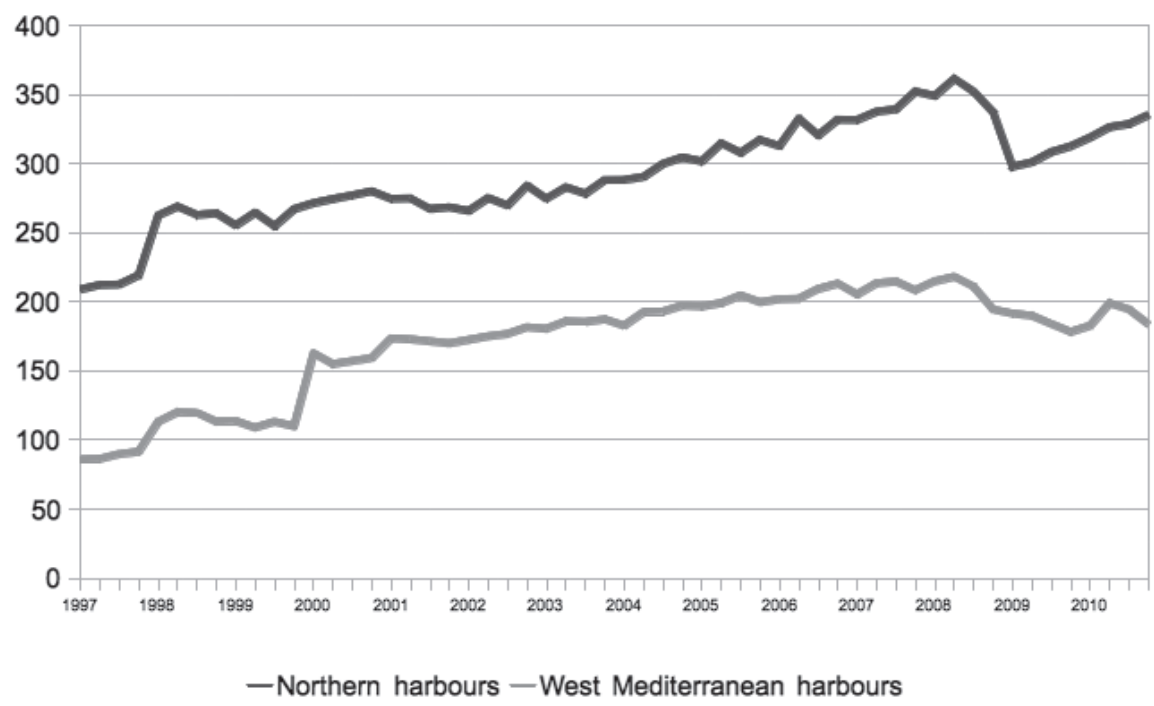

Within the respective domestic maritime transport policy communities as well as at the EU level, various efforts have been made to understand how performance of West Mediterranean ports can be improved. The policy discourse generally focused on the issues that arose from the limited collaboration between actors of the maritime infrastructure and between the maritime and the broader transport network within the EU and EU member states. Policy documents (such as the Green Book "Towards a future Maritime Policy for the Union: a European vision for the oceans and seas", 2006) outlined the benefits that were expected to arise out of improved performance of the maritime transport infrastructure in terms of economic growth, environmental sustainability, and tourism. In part, these policy concerns were addressed by legislative reforms that were conducted at the EU member state level. In part, however, efforts to change the institutional system of the maritime infrastructure at the EU level failed to result in any legislative reform.

In France, during the last century ports were long afflicted by inefficient institutional arrangements (that consisted of the 'autonomous port' or Établissement Public Mixte, a public undertaking with a dual public and private nature), social unrest (e.g., maritime workforce strikes that took place in early 1990s, that undermined the reliability of French ports in the eyes of carriers), and constraining legal frameworks (e.g., port operators could not set prices and had no incentive to invest in port infrastructure). During the 1990's and 2000's, a bunch of reforms (in 1992, 2004, and 2008) radically reconfigured the institutional system of French maritime infrastructure. 
The current institutional arrangement provides that the Port Authorities focus on planning (e.g., port infrastructure development and maintenance) and regulatory functions (e.g., enforcement of security and safety measures), while port services are tendered out through transparent and non-discriminative selection procedures to private bidders. The current policy discourse on the maritime transport industry mainly focuses on the need for investments aimed at improving efficiency, for a better industrial organization of containers terminals, for stronger integration between ports and hinterland transport networks, and for a more peaceful social climate among port stakeholders (Cour des Comptes, 2008). The French government is especially committed to supervise the development of seven major seaport, including especially Le Havre and Marseille, that host about two thirds of national maritime traffic.

In Italy, the issue of the competitiveness of national ports within the overall European maritime transport industry has long attracted the attention of the domestic transport policy community. While geography puts Italian ports at advantage with respect to other Western and Northern European harbors (as carriers along the Europe-Asia "pendulum route" may save up to about five days' travel), their performance is negatively affected by inadequate hinterland infrastructure, inefficient bureaucracy, and obsolete port infrastructure (e.g., shallow water, small storage facilities and parking areas, and inadequate cranes) (Beretta et al., 2009). In the past, ports had been typically administered through "port management" organizations (Organizzazioni Portuali) that concentrated both public functions and operation of port services in monopoly conditions (Autorità Garante della Concorrenza e del Mercato, 1992). In 1994, a reform provided that "port management" organizations were reincorporated as Port Authorities, that planning and regulation were separated from operational functions, and that port operation concessions and licenses were allocated according to transparent and non-discriminatory criteria. The reform allowed some private operators to break into the maritime transport industry, although it missed to fully open national ports to competitive pressures (e.g., Port Authorities set a maximum number of authorizations to operate port services, and still retain control various port activities such as utilities, ship repair and maintenance, and general interest services such as pilotage) and to suppress anti-competitive practices (e.g., collusion between incumbent port operators, privileged positions held by operators partially owned by the Port Authorities, predatory pricing, and subsidies granted to the workforce of former "port management" organizations).

In Spain, until 1992 the port system included four "autonomous ports" (Barcelona, Bilbao, Huelva and Valencia) and dozens of other harbors, generally managed by public authorities (Juntas del Puerto) in a very decentralized way. The 1992 reform (later modified in 1997) deeply reconfigured the national institutional arrangement of the maritime infrastructure, as it provided that all ports of national interest were governed by Public Authorities subject to supervision by the national Spanish State Port Agency (SSPA) named Puertos del Estado. The SSPA coordinates the development and operation of national ports, especially through the provision of national funds 
Alberto Asquer

subjected to the condition of maintaining economic self-sufficiency of the overall national maritime transport system, and conducts inspections on the efficiency of Port Authorities. At the local level, the Port Authorities enjoy financial autonomy (especially after a legislation passed in 2003), exercise discretion in promoting commercial activities, perform regulatory functions, and directly operate port services of general public interest status. This institutional arrangement (combined with other interventions, such as change of employment status of port workforce from civil servants to private sector) has generally favored the entry of private operators in financing port infrastructure development and managing port services.

Only partially did changes of the institutional arrangement of the maritime infrastructure in West Mediterranean Sea take place at the national level, however. As EU member states, France, Italy, and Spain are embedded within the political and policy processes conducted within the EU Commission and EU Parliament. As such, they are expected to transpose any EU directives concerning maritime transport policy into their domestic institutional systems. In this respect, the evolution of port infrastructure in West Mediterranean Sea needs to take into account the development of EU maritime transport policy. Early EC treaties, however, did not include maritime transport within the jurisdiction of the Common Transport Policy (Chlomoudis and Pallis, 2005, 2006; EU, 2006). In the 1980's only did the EU Council adopt regulations concerning opening market access to maritime transport services, liberalization of cabotage, and application of competition rules to maritime transportation. During the 1990's, some steps were made to formulate an explicit EU maritime transport policy, including the 1997 Green Paper on Sea Ports and Maritime Infrastructure. Eventually, a couple of EU directives ("port packages") were proposed in 2001 and 2004, but they failed to gain consensus among stakeholders and they were rebuffed by the European Parliament. As a result, setting aside some policy position documents (e.g., the White paper on a European Transport Policy for 2010) the EU currently lacks any authoritative formulation of a maritime transport policy as well as any common institutional arrangement of the maritime infrastructure (Pallis and Tsiotis, 2008).

The difficulties encountered twice to pass the proposed EU directives are illustrative of the issues at stake in the reform of the institutional arrangement of the maritime infrastructure. The 2001 directive proposal aimed to establish, at minimum, common rules for the free provision of port services, the issue of concessions and authorizations for port services operations, a limited number of port service providers, self handling, a limited duration of individual concessions and authorizations, and the procedures for awarding concessions and authorizations. A further objective was to promote the presence of at least two providers for every port operation, including navigational services (pilotage, towage, and mooring), cargo-handling services (stevedoring, stowage, transshipment, and other intra-terminal transport, storage, depot, warehousing, and cargo consolidation), and passenger services (embarkation and disembarkation). The proposal was highly controversial, however, especially with respect to the services of pilotage, self-handling of cargoes, and the authorization of 
service providers, and was rejected by the EU Parliament in November 2003. Within a few months, the EU Commission proposed a new EU directive that contained a stricter and mandatory regime of authorizations, shorter maximum durations for each authorization, and a new and broader definition of self-handling (Pallis and Vaggelas, 2005). Also the second EU directive proposal, however, missed to gather the consensus of the EU Parliament in the January 2006 vote.

The failure to gain support for the proposed EU directives may be ascribed, in part, to the fundamental divergence between perceptions, stakes, and objectives of the many actors that populate the maritime transport industry, including Port Authorities, shipowners, shippers, maritime workforce, governments, consumers, and others. A review of the policy positions held by these stakeholders is illustrative of the difficulties encountered in assembling a supportive coalition for passing the proposed policy reform. Port Authorities, first, were jointly represented by the European Sea Ports Organisation (ESPO). ESPO contained very different policy position that included both those of Northern European harbors (that had generally implemented a 'landlord' model for governing port development and operations) and those of Mediterranean ports (that often still retained ownership and control of large part of port services). With respect to the changes of institutional arrangement of the maritime infrastructure contained in the proposed EU directives, however, Port Authorities generally agreed to express their discontent with both the prospect of allowing self-handling by shipping companies, shortening the duration of authorizations (that often used to extend up to 75 or 99 years), and reducing the transition period between the adoption of the reform package and its implementation. Even stronger opposition to the proposed EU directives was expressed by the Federation of Private Port Operators (FEPORT).

Shipowners constituted the other main influential player of the maritime infrastructure industry at that time (Pallis, 2002, 2007; Aspinwal, 1995). Jointly represented by the European Community Shipowners Association (ECSA), shipowners unanimously advocated the liberalization of port services and the dismantling of traditional monopolies of port services. They supported the proposed EU directive by arguing, for example, in favor of authorizations granted on the basis of professional efficiency criteria, of shortened duration of concessions and licenses, of the presence of at least two service providers for each port service, and of allowing self-handling to ocean shipping personnel. Most of shipowners' positions conflicted with those of other stakeholders, especially Port Authorities and the maritime workforce that generally opposed rules that threatened their prerogatives in running port services. By and large, shipowners were rather backed by the shippers that (especially through the European Shippers Council, or ESC) generally championed 'full liberalization' of port services.

The maritime workforce, once a dominant player in the industry, was exposed to the threat of losing most of its traditional prerogatives and protections. Although this class of actors is typically fragmented into various trade union representations (e.g., at the EU level, the European branch of the International Transport Workers Federation, the European Transport Workers Federation, and the International Dockworkers 
Alberto Asquer

Council), the maritime workforce was able to effectively lobby against any reform initiative within the maritime infrastructure industry. They fiercely opposed the proposed EU directives, especially the mandatory character of authorizations and self-handling, on the basis of safety and social grounds. More generally, the maritime workforce tended to oppose any liberalization of port services that put at risk the longestablished exclusive role that dockworkers played in the provision of port services.

Other actors played a rather more peripheral role. The national governments, for example, generally influenced the maritime infrastructure through the provision of legislation and financial resources (especially, state aids for funding infrastructure development and maintenance), but generally they do not (in most contemporary institutional arrangements) directly run port services. Governments are generally concerned, however, with improving maritime infrastructure performance, as this relates to increased traffic, tax revenues, and jobs. Within the episode of the making of the proposed EU directives, however, national governments seemed mostly concerned with avoiding creating uncertainty in the legal and regulatory systems that would undermine the value of investments in installed infrastructure assets and alienate existing and prospective investors. Additionally, while governments of Mediterranean countries generally supported the proposed EU directives as they would have stimulated more intra-port competition and infrastructure performance, Northern European ones were typically tepid towards changing existing institutional arrangements, provided that their ports had already been opened to private participation and competitive pressures.

Finally, the consumers could ostensibly benefit from liberalization and procompetitive measures introduced in the maritime infrastructure industry. This class of actors, however, is minimally organized into associations or other forms of representation, with the effect that consumers' perspective rarely contributes significantly to the policy-making process. A relatively minor role was also played by other interest groups, such as the association of freight forwarders (CLECAT), the one of tug-owners (ETA), the European Maritime Pilots Association (EMPA), and the European Boatmen Association (EBA). The positions and stakes of these actors within the reconfiguration of EU institutional arrangement of the maritime infrastructure were highly fragmented. CLECAT and EBA, for example, broadly supported the proposed EU directives, but the former showed to endorse self-handling while the latter did not. EMPA strongly opposed the opening of pilotage services to competition, on the ground that the pilotage service was intended to serve the general public interest for safety rather than achieving profits. Finally, ETA did not support the proposed EU directive, presumably because of contrary views on the regulation of towage.

\section{DISCUSSION}

The case of the maritime transport industry in West Mediterranean Sea sheds some light into the issue of how actors coordinate their efforts to realign technological and 
institutional systems in face of evidence of dissatisfying infrastructure performance in both the economic, public, and technical dimensions. Evidence from the case suggests that actors of the maritime transport industry generally shared a consensual view on the dissatisfying performance of the maritime infrastructure in West Mediterranean Sea, at both the EU and member state levels (especially, in terms of congestion of Northern European ports and under-utilization of capacity of Southern European ones). Actors also seemed to share the view that the lack of competitive pressures and of an independent regulator put into question whether port services were efficiently priced and whether all customers of port services that were willing to pay the set prices were actually served. The services of consumer interest generally seemed to satisfy criteria of quality, accessibility, affordability, and reliability, although further actions were needed to ensure access to port and hinterland infrastructure (De Langen, 2008).

From a static perspective, the performance of the maritime infrastructure can be explained by using the coherence framework in the "original" formulation (Finger et al., 2005). According to this view, the dissatisfying level of maritime infrastructure performance in West Mediterranean Sea can be explained by defects in the technical functions that characterize the operation of maritime infrastructure. Scattered evidence from the case provides some support for this account. First, we can notice that the interconnection of maritime infrastructure (i.e., the interface between ports and other transport networks in the port hinterland and the adequacy of the infrastructure for the containerization of traffic) is partially inadequate, both because of obsolete port infrastructure (e.g., shallow water that prevents mooring of large container carriers) and underdeveloped connections with land-based transport networks (e.g., railways, highways). The interoperability of maritime infrastructure (i.e., standardization of items size, handling and storage facilities, compatible norms and customs, and regulatory conditions for port service access) could be improved in many respects (e.g., new cranes for adequately handling different items size, and more transparent and non-discriminatory process for port service access). System management requires novel devices for re-integrating port operations and streamlining bureaucracy, especially after the demise of traditional "port organizations". Finally, capacity management should be certainly improved, especially taking into account the hub-and-spoke features of most of West Mediterranean maritime infrastructure.

As a further step to explain the performance of the maritime infrastructure, we can look at whether there is any mismatch between the mechanisms of coordination, scope of control, territorial resolution, and speed of adjustment of the technological and institutional systems. In general, the case provides some evidence that the technological and institutional systems of maritime infrastructure are not perfectly aligned (Table 1). Technological and institutional systems are coordinated through different mechanisms that resort to more or less centralized or decentralized arrangements. The scope of control of maritime infrastructure operations may extend to either specific terminals or activities or to the whole port system or beyond (e.g., control of the harbor-hinterland interface or of the whole national port system). 
Alberto Asquer

Territorial resolution of technological and institutional systems may focus on very specific activities or extend to nation-wide or super-national boundaries. Finally, the speed of adjustment may relate to either short time frames of handling operations or to relatively long periods of investment processes. Provided such variety of features of the technological and institutional systems, port operators may find themselves carrying out technical tasks that require coordination and control within territorial areas and time frames different from those stipulated by the institutional arrangement. For example, the technical task of planning and coordinating intermodal transport typically requires activities to be carried out within and beyond the port area, while the institutional arrangement may restrict competences of key actors (e.g., Port Authorities) to the territory of the harbor only. As another example, the technical task of upgrading port equipment and facilities typically requires investments with relatively long depreciation periods, while the institutional arrangement may limit the duration of concession contracts to shorter time frames.

Table 1. Features of technical and institutional systems of maritime infrastructure in West Mediterranean Sea

\begin{tabular}{|c|c|c|}
\hline & Technological systems & Institutional systems \\
\hline $\begin{array}{l}\text { Mechanisms of } \\
\text { coordination }\end{array}$ & $\begin{array}{l}\text { Various kinds of technical methods } \\
\text { of coordination (e.g., centralized } \\
\text { piloting within harbors, } \\
\text { decentralized cargo handling } \\
\text { negotiations, and peer-to-peer } \\
\text { arrangements between shippers and } \\
\text { shipowners) }\end{array}$ & $\begin{array}{l}\text { Various kinds of institutional } \\
\text { methods for coordination (e.g., } \\
\text { centralized harbor development } \\
\text { planning, decentralized service } \\
\text { delivery) }\end{array}$ \\
\hline Scope of control & $\begin{array}{l}\text { Generally the whole port or specific } \\
\text { terminals, but it may also extend } \\
\text { towards activities in the port } \\
\text { hinterland (e.g., services related to } \\
\text { intermodal rail facilities) }\end{array}$ & $\begin{array}{l}\text { Mostly corresponding to the Port } \\
\text { Authority jurisdiction, but some } \\
\text { contractual arrangements may } \\
\text { restrict control to some specific } \\
\text { areas (e.g., terminals), while control } \\
\text { of other activities may extend to the } \\
\text { national or super-national level }\end{array}$ \\
\hline Territorial resolution & $\begin{array}{l}\text { Mostly fine-grained (e.g., keyed to } \\
\text { the harbor or specific terminals or } \\
\text { docks), but also partially extended } \\
\text { up to the global scale }\end{array}$ & $\begin{array}{l}\text { Partially keyed to the whole port or } \\
\text { specific terminals, but also partially } \\
\text { related to nation-wide or super- } \\
\text { national jurisdictions (e.g., national } \\
\text { and possibly EU legislation) }\end{array}$ \\
\hline Speed of adjustment & $\begin{array}{l}\text { Various kinds (e.g., hours allocated } \\
\text { to handling, decades during which } \\
\text { assets depreciate) }\end{array}$ & $\begin{array}{l}\text { Various kinds (e.g., either relatively } \\
\text { short operational activities or long } \\
\text { investment processes) }\end{array}$ \\
\hline
\end{tabular}

From a dynamic, rather than static, perspective, the issue at stake is to account for why actors within the maritime industry have not been able to improve the cohesion between the technological and institutional systems over time. The case provides some evidence 
that, indeed, during the 1990's and 2000's some efforts were made to improve the alignment between the technological and institutional systems of maritime infrastructure by passing reforms in France, Italy, and Spain and investing in additional port terminals, hinterland transport networks, and storage facilities. The case also suggests, however, that actors within the EU maritime transport industry have not been able to pass the proposed EU reform packages, and that the development of the maritime infrastructure is hampered by limited participation of private capital financing. A theory of technological and institutional change in network industries should provide an answer as to why actors of the maritime transport industry seem "stuck" with technological and institutional systems despite the fact that they are publicly regarded as conducive to dissatisfying overall performance of the network infrastructure.

Following the theoretical argument sketched above, a tentative answer is that, first, we should take into account the role played by the different dimensions of performance that actors care about in the private and public sphere. In the public policy discourse, actors of the EU maritime transport industry seem to share a concern with the need for the improvement of the maritime infrastructure within the context of increasing traffic volume at the global scale. Privately, however, different actors hold contrasting standards for performance measurement and assessment. Actors related to Northern European harbors, in particular, may not find it advantageous to help fixing performance gaps of southern competitors for the global maritime traffic. Accordingly, they may restrain from participating in the design and adoption of institutional changes that may bring about performance improvements of West Mediterranean Sea ports. In other words, the arena for EU-wide policy change calls into play actors whose private performance interests diverge from those of actors who genuinely care about improving the performance of West Mediterranean Sea ports.

As an additional answer, we should also take into account difficulties encountered by actors in coordinating their strategies for investment as well as for changing rules of maritime infrastructure. The redesign of the institutional arrangement of the maritime infrastructure seems obstructed by the resistance of some actors against regulations that erode incumbent positions and rents. The mechanisms that impede better coherence between technological and institutional systems, therefore, seem to mutually reinforce each other: more investments in technological systems are needed in order to strengthen the influence of maritime actors that support institutional change (e.g., shipowners and shippers), while additional support for policy reform is needed in order to redesign the institutional arrangement of the maritime infrastructure in such a way as to provide better industry climate for investments. In other words, the mismatch between the installed technological system on the one hand, and the institutional arrangement of the infrastructure system on the other one, seems to originate a "mutually inhibiting feedback" between the processes of technological and institutional change.

This analysis of the case suggests that status quo conditions may inhibit both technological and institutional change processes. These conditions include, in 
Alberto Asquer

particular, an incentive structure that does not induce investments in the technological system and efforts to change the institutional arrangement of the maritime infrastructure. The persistence of lack of coherence between the technological and institutional systems, therefore, can be explained by the reciprocal effect of technical features and institutional arrangements of the maritime infrastructure on each other: the installed technological system results in established rent positions that make some actors resist institutional change, while the institutional arrangement does not adequately induce actors to invest in improved technological systems.

A further question arises, then, concerning whether the "mutually inhibiting feedback" between the processes of technological and institutional change may be interrupted and, possibly, reversed. A tentative answer is that, while efforts to improve the coherence between technological and institutional systems may languish in the short term, more favorable conditions may arise in the medium-long time perspective if general trends within the maritime industry persist. The increasing demand of maritime transport, the flow of technological innovations, and the diffusion of liberalization of maritime services may contribute reshaping the structure and interests of some actors within the maritime infrastructure, at least in part of the network. The accumulation of more capital-intensive technical systems, in particular, may diminish the importance of maritime workforce within the maritime infrastructure policy domain, with the effect of weakening the policy coalition that opposes radical institutional changes. The progressive implementation of liberalization policies in the maritime infrastructure, furthermore, may attract entrepreneurial and financial resources that result in new investments in the maritime infrastructure technological systems. It is possible that better technological and institutional coherence in the maritime transport industry will be achieved when conditions are conducive to a "mutually supportive feedback" between the processes of technological and institutional change.

\section{CONCLUSIONS}

This study aims to contribute developing an improved theory of technological and institutional change in network industries building on the arguments provided by the technological and institutional coherence framework (Finger et al., 2010; Duthaler and Finger, 2010; Crettenand et al., 2010; Finger and Künneke, 2009, 2006; Scholten, 2005; Finger and et al., 2005). With respect to the early steps made in this direction (Finger et al., 2010; Crettenand, 2011), this study argues that a theory of technological and institutional change in network industries should include attention to why actors become interested to attain higher performance expectations and why they exert their power to change rules and technical features of infrastructure. As suggested in the case of the maritime transport industry in West Mediterranean Sea, an important role can be played by the variety of private and public dimensions of performance of the network 
industry and by the mutual interaction between status quo conditions in the technological and institutional systems. Actors may not be interested in improving infrastructure performance because of privately held criteria for definition, measurement, and assessment of performance that may well differ from those that are discussed in the public sphere. Additionally, actors may be "stuck" with technological and institutional systems that result in sub-satisfying performance because of incentive structures that do not induce investments and efforts to change the rules of infrastructure regulation.

This study bears some limitations that should be duly acknowledged. First, the case of the maritime network industry in West Mediterranean Sea deserves further research in order to gain a more fine-grained understanding of the evolution of technical and institutional systems at the local (i.e., harbor), national, and super-national (i.e., EU) level, of the differences between the processes of development of the technical and institutional systems across countries and harbors, and of the interrelationships between the technical and institutional change processes at different levels (i.e., between the EU and the domestic maritime infrastructure policy arenas). Second, the case of the maritime network industry could be compared with other network industry cases, for the sake of further elaborating how status quo conditions or other context factors affect the co-evolution of technological and institutional systems. Lastly, the development of an improved theory of technological and institutional change in network industries built on the coherence framework could eventually result in the formulation of testable hypothesis about what affects or prevents the convergence between the technical and institutional systems of infrastructure.

Finally, this study bears some implications in terms of policy advice. If the steps made here in the development of an improved theory of technological and institutional change in network industries are correct, then policy analysts should pay careful attention to understanding which dimensions of performance actors of the network industry really care about, and whether status quo conditions inhibit both investments and efforts to change rules of infrastructure regulation. Within certain scenarios, actors of the network industry may be willing and able to improve the coherence between the technological and institutional systems of infrastructure, and the closure of the "performance gap" between actual and desired results may be just a matter of time. Within other scenarios, instead, actors may be unable to share common performance concerns and to overcome the obstacles to invest and to redesign the institutional arrangements. In the latter case, policy advocates should devise interventions to improve awareness of issues about public dimensions of performance of the network industry and timely orchestrate efforts to coordinate both technological and institutional change.

\section{REFERENCES}

Autorità Garante della Concorrenza e del Mercato (1992) Indagine conoscitiva nel settore dei servizi portuali. Rome: AGCM. 
Aspinwall, M. (1995) Moveable Feast: Pressure Group Conflict and the European Community Shipping Policy. Ashgate, UK: Aldershot.

Beretta, E., Delle Vacche, A. and Migliardi, A. (2009) Il sistema portuale italiano: un'indagine sui fattori di competitività e di sviluppo. Rome: Bank of Italy. Questioni di Economia e Finanza (Occasional Papers No. 39).

Chlomoudis, C.I. and Pallis, A.A. (2005) “The EU Port Policy in a Historical Perspective", European Research Studies, 8(1): 21-42.

Chlomoudis, C.I. and Pallis, A.A. (2006) "EU Port Policy: A process of inexorable policy integration", In M.C. Hatzioannou and G. Harlaftis (eds), Following the Nereids: Sea Routes and maritime business, $16^{\text {th }}-20^{\text {th }}$ centuries. Athens: Kerkyra Publications, 155-163.

CoAse, R. (2005) “The institutional structure of production", In C. Ménard and M. Shirley (eds), Handbook of New Institutional Economics. New York: Springer, 31-65.

Cour Des Comptes (2008) Rapport public thématique sur les ports français face aux mutations du transport maritime: l'urgence de l'action. Paris: Cour des Comptes.

Crettenand, N. (2011) "Pump-storage small hydropower as an example of co-evolution between institutions and technologies", $4^{\text {th }}$ Conference on Competition and Regulation in Network Industries, Brussels.

Crettenand, N., Laperrouza, M., Finger, M. and Duthaler, C. (2010) Performance and coherence in network industries. Discussion paper series on the coherence between institutions and technologies in infrastructures, WP10-03.

Cullinane, K. (2011) International Handbook of Maritime Business. Cheltenham, UK: Edward Elgar.

Defilippi Angeldonis, E.F. (2010) Access Regulation for Naturally Monopolistic Port Terminals: Lessons from Regulated Network Industries. PhD Thesis, Erasmus University Rotterdam.

De Langen, P.W. (2008) Ensuring Hinterland Access: The Role of Port Authorities. OECD-International Transport Forum Joint Research Centre, Discussion Paper 2008-11.

De Rus, G., Román, C. and Trujillo, T. (1994) Actividad Económica y Estructura de Costes del Puerto de La Luz y de Las Palmas. Madrid: Ed. Cívitas.

Dosi, G. (1982) “Technological paradigms and technological trajectories”, Research Policy, 11: 147-162.

Dosi, G. and Nelson, R.R. (1994) "An introduction to evolutionary theories in economics", Journal of Evolutionary Economics, 4(3): 153-172.

Duthaler, C. and Finger, M. (2010) The missing link between coherence and performance in network industries. Discussion paper series on the coherence between institutions and technologies in infrastructures, WP10-01.

Economides, N. (1996) “The Economics of Networks", International Journal of Industrial Organization, 14: 673-699.

Estache, A., Gonzalez, M. and Trujillo, L. (2001) Technical efficiency gains from port reform: the potential for yardstick competition in Mexico. World Bank Policy Research Working Paper No. 2637. 
Estache, A., de la Fé, B.T. and Trujillo, L. (2003) "Sources of efficiency gains in port reform: A DEA decomposition of a Malmquist TFP Index for Mexico", Utilities Policy, 12(4): 221-230.

EU (2006) Maritime Transport Policy: Improving the competitiveness, safety and security of European shipping. Belgium: EU Commission Directorate-General for Energy and Transport.

Eurostat (2011) Quarterly and annual data based on Council Directive 95/64/EC. http://epp.eurostat.ec.europa.eu/portal/page/portal/transport/data/database.

Finger, M. and KüNNEke, R. (2006) “The need for coherence between institutions and technology in liberalized infrastructures: the case of network unbundling in electricity and railways", Paper presented at the $5^{\text {th }}$ Conference on Applied Infrastructure Research, Berlin, 6-7 October.

Finger, M. and Künneke, R. (2007) "The co-evolution between institutions and technology in liberalized infrastructures: the case of network unbundling in electricity and railways", The International Society for New Institutional Economics, Reykjavik, Iceland.

Finger, M. and KüNNEKE, R. (2009) Exploring socio-technical governance regimes in liberalizing network industries. Discussion paper series on the coherence between institutions and technologies in infrastructures, WP09-01.

Finger, M., Groenewegen, J. and Künneke, R. (2005) “The quest for coherence between institutions and technologies in infrastructures", Journal of Network Industries, 6(4): 227-259.

Finger, M., Crettenand, N., Laperrouza, M. and Künneke, R. (2010) Governing the dynamics of the network industries. Discussion paper series on the coherence between institutions and technologies in infrastructures, WP10-02.

Geels, F. (2004) "From sectoral systems of innovation to socio-technical systems. Insights about dynamics and change from sociology and institutional theory", Research Policy, 33: 897-920.

Gibbons, J. and Gwin, H. (1985) “Technology and Governance”, Technology in Society, 7: 333-352.

Glachant, J.-M. and Finon, D. (1999) Why Do European Union's Electricity Industries Continue to Differ? A New Institutional Analysis. ADIS Working Paper, No 1999-01.

Göttinger, H.W. (2003) Economies of Network Industries. London: Routledge.

Karlsson, C., Anderson, W.P., Johansson, B. and Kobayashi, K. (2007) The Management and Measurement of Infrastructure: Performance, Efficiency and Innovation. Northampton, MA: Edward Elgar Publishing.

Kessides, I. (2004) Reforming Infrastructure: Privatization, Regulation and Competition. Oxford: Oxford University Press.

KüNNEKE, R.W. (2008) "Institutional reform and technological practice: the case of electricity", Industrial and Corporate Change, 17(2): 233-265. 
Alberto Asquer

Künneke, R.W. and FInger, M. (2007) "Technology matters: the cases of the liberalization of the electricity and railways", Competition and Regulation in Network Industries, 8(3): 303-335.

Künneke, R.W., Groenewegen, J. and Ménard, C. (2008) Aligning institutions with technology: Critical transactions in the reform of infrastructures. Working Paper, TU Delft.

MÉnARD, C. (2005), “A new institutional approach to organization”, In C. Ménard and M. Shirley (eds), Handbook of New Institutional Economics. New York: Springer, 281-318.

Nelson, R. and Winter, S. (1982) An Evolutionary Theory of Economic Change. Boston: Harvard University Press.

Newberry, D. (2001) Privatization, Restructuring, and Regulation of Network Industries. Cambridge: MIT Press.

Pallis, A.A. (2002) The Common EU Maritime Transport Policy. Ashgate, UK: Aldershot.

PAllis A.A. (2007) "Whither Port Strategy? Theory and Practice in Conflict", In A.A. Pallis (ed), Maritime Transport: The Greek Paradigm, Research in Transportation Economics, No. 21, Elsevier: London, 345-386.

PAllis, A.A. and Tsiotis, G.-S.P. (2008) "Maritime interests and the EU port services directive", European Transport, 38: 17-31.

Pallis, A.A. and Vaggelas, G.K. (2005) "Port Competitiveness and the EU 'Port Services' Directive: The Case of Greek Ports", Maritime Economics and Logistics, 7(2): 116-140.

Robinson, R. (2002) "Ports as elements in value-driven chain systems: the new paradigm”, Maritime Policy and Management, 29(3): 241-55.

Scholten, D. (2009) The role of coherence in the coevolution between institutions and technologies, Discussion paper series on the coherence between institutions and technologies in infrastructures, WP09-03.

Schumpeter, J.A. (1942) Capitalism, Socialism, and Democracy. New York: Harper and Brothers.

Tongzon, J. and Heng, W. (2005) "Port privatization, efficiency and competitiveness: Some empirical evidence from container ports (terminals)", Transportation Research Part A: Policy and Practice, 39(5): 405-424.

Tovar, B., Trujillo, L. and Jara-Díaz, S. (2004) "Organization and regulation of the Port Industry: Europe and Spain”, In P. Coto-Millan (ed), Essays on Microeconomics and Industrial Organisation. Germany: Physica-Verlag, 189-207.

Trujillo, L. and Nombela, G. (2002) "Seaports", In A. Estache and G. de Rus (eds), Privatization and Regulation of Transport Infrastructure. Washington, D.C.: The World Bank, 113-170.

Williamson, O. (1975) Markets and hierarchies. Analysis and Anti-Trust implications. New York: Free Press.

Williamson, O. (1985) The Economic Institutions of Capitalism. New York: Free Press. 